7. Reprod. Fert. (1973) 35, 225-233

\title{
PLASMA HORMONE LEVELS IN BEEF COWS WITH INDUCED MULTIPLE OVULATIONS*
}

\author{
D. M. HENRICKS, J. R. HILL, JR, J. F. DICKEY \\ AND D. R. LAMOND \\ Departments of Food Science, Animal Science and Dairy Science, \\ Clemson University, Clemson, South Carolina 29631, U.S.A., and \\ Syntex Research, Palo Alto, California 94304, U.S.A.
}

\section{(Received 5th October 1972)}

\begin{abstract}
Summary. Doses of 0, 1600 or 3200 i.u. PMSG were administered on Day 16 of an oestrous cycle to twenty-four beef heifers. Jugular blood was collected at 08.30 and 17.30 hours each day until oestrus and at 0 , $3,6,9$ and $12 \mathrm{hr}$ after the beginning of oestrus. The plasma was analysed for total oestrogen, progesterone and LH concentrations. The heifers were killed 3 to 8 days after mating, and their ova and ovaries were examined to determine the incidence of fertilization, numbers of CL, and numbers of follicles greater than $10 \mathrm{~mm}$ diameter. The low dose of PMSG caused less variation in number of ovulations and fewer large follicles than the high dose, though the mean number of fertilized ova was similar. The hormonal patterns were related to the dose of PMSG. Plasma progesterone levels remained elevated for a longer period and decreased more rapidly in the animals given 3200 i.u. than in the others. Total oestrogen began to rise about $48 \mathrm{hr}$ before oestrus in all groups and reached highest levels and remained elevated for longest periods in the animals given 3200 i.u. PMSG. The LH peaks occurred at $0 \mathrm{hr}$, $3 \mathrm{hr}$, or $6 \mathrm{hr}$ after the beginning of oestrus in cows treated with 3200 i.u., 1600 i.u. or nil PMSG, respectively.
\end{abstract}

\section{INTRODUCTION}

Methods of inducing multiple births in cattle, as by treatment with $\mathrm{FSH}$ or PMSG, are receiving much attention. Hammond (1949) and Gordon, Williams \& Edwards (1962) reported that a single injection of PMSG could induce multiple ovulations and multiple pregnancies, though there was considerable variation among animals in the rate of ovulation. Treatment with FSH has been shown to produce less variable ovulation rates, but a series of injections of the hormone is required due to its short half-life compared to that of PMSG (Dziuk, Donker, Nichols \& Petersen, 1958). Fecundity (\% of calves weaned/ cows treated) was $108 \%$ in lactating beef cows treated with PMSG and $104 \%$

* Published with the approval of the Director of the Agricultural Experiment Station as Technical Contribution No. 1043. 
in lactating beef cows after FSH treatment (see Bellows \& Short, 1972, for details).

After administering PMSG to lactating beef cows, plasma oestrogen and LH levels were greater in cows with multiple ovulations than in cows having one ovulation (Henricks \& Lamond, 1972). The ovulation rate was affected by removing the calves at different times in relation to PMSG treatment. Withholding food immediately before PMSG administration reduced the variance of ovulation (Lamond, 1970, 1972). Further advances in the use of PMSG will depend on a better understanding of the effect of PMSG on endogenous hormone patterns and interrelationships. Variables such as withholding food were not introduced into the present experiment, which was conducted to determine the effects of PMSG injection on Day 16 of an oestrous cycle on (1) plasma total oestrogen, progesterone and $\mathrm{LH}$ concentrations during the follicular phase and oestrus, and (2) ovarian morphology, ovulation and fertilization after mating in the beef heifer.

\section{MATERIALS AND METHODS}

\section{Animals}

Twenty-four beef heifers, approximately 20 months old, were randomly allotted to three treatments. All animals received a single subcutaneous injection on Day 16 of an oestrous cycle in June 1971. Group 1 received $1 \mathrm{ml}$ physiological saline; Groups 2 and 3 received 1600 or 3200 i.u. PMSG, respectively. Only cows with at least two oestrous cycles of between 18 and 24 days were used in the experiment. Blood was collected from the jugular vein into heparinized vacuum tubes immediately before injection on Day 16 and on a twice daily basis ( 08.30 and 17.30 hours) until oestrus. From the onset of oestrus, blood was taken at $0,3,6,9$ and $12 \mathrm{hr}$. The blood was placed on ice and centrifuged at $4^{\circ} \mathrm{C}$ within $2 \mathrm{hr}$ after collection. Plasma was stored at $-20^{\circ} \mathrm{C}$.

Each heifer was mated to two bulls. Between 3 and 8 days after mating, all cows were slaughtered. For each heifer, the number and size of CL and follicles and the weight of the ovaries were determined. The number of CL at slaughter was assumed to represent the number of ovulations. Ova were collected and examined for the appearance of blastomeres and the presence of spermatozoa in the zona pellucida.

\section{Assay of plasma for hormones}

All plasma samples were assayed for total plasma oestrogen concentration using radioimmunoassay. A description of the procedure and its validation in our laboratory has been reported previously (Henricks, Dickey \& Hill, 1971). The supply of $\left[6,7-{ }^{3} \mathrm{H}\right]$ oestradiol- $17 \beta$ (specific activity of $40 \mathrm{Ci} / \mathrm{mmol}$ ) was purchased from New England Nuclear Corp., Boston, Mass.

Plasma LH concentration in all samples was determined by a double antibody RIA as adapted from the method of Niswender, Reichert, Midgley \& Nalbandov (1969). Antiserum against bovine LH (B-225) was used at a dilution of $1: 100,000$. Bovine LH (LER-1072-2) was used for iodination with sodium 
$\left[{ }^{131}\right.$ I] iodide (Iso-Serve Division, Cambridge Nuclear Corp., Boston, Mass.) and for preparation of the standard concentrations of the hormone.

The plasma concentration of progesterone was determined by a radioimmunoassay adapted from the method of Thorneycroft \& Stone (1972). In our laboratory, $100 \mu \mathrm{l}$ per tube of a 1:5000 dilution of the antiserum bound $50 \%$ of the $\left[{ }^{3} \mathrm{H}\right]$ progesterone. The quantities of authentic progesterone (Mann Biochemical Co., Orangeburg, N.Y.) placed in each assay were $6,10,20,50$, 100,200 and $400 \mathrm{pg}$. The response in $\mathrm{ct} / \mathrm{min}$ was used to construct a standard curve. Thorneycroft \& Stone (1972) reported cross-reactions of the antiserum $(>1 \%$ ) with $11 \beta$-hydroxyprogesterone, pregnenolone, 17-hydroxyprogesterone, deoxycorticosterone and $5 \beta$-pregnane-3,20-dione. In testing for cross-reactions with progestins present in significant quantities in bovine plasma, we measured $3.3 \%$ and $0.6 \%$ cross-reactions with 17 -hydroxyprogesterone and $20 \beta$-hydroxyprogesterone, respectively. Because of the small amount of cross-reaction, a simple petroleum ether extraction $(2 \times)$ of the plasma was the only step before incubating the ether extract with the antiserum. In each assay, $\left[6,7-{ }^{3} \mathrm{H}\right]$ progesterone was added to three tubes to determine the efficiency of extraction. The mean \pm S.E.M. for all assays was $96.0 \pm 0.4 \%(n=12)$. The form of the radioactive hormone incubated with the antibody was $\left[1,2,6,7-{ }^{3} \mathrm{H}\right]$ progesterone (specific activity, $81 \mathrm{Ci} / \mathrm{mmol}$ ).

A buffer $(\mathrm{pH} \mathrm{7.0)}$ consisting of $0.01 \mathrm{~m}$-sodium phosphate, $0.9 \% \mathrm{NaCl}$ and $0.1 \%$ Knox gelatine was used to make the solutions of antiserum, radioactive progesterone and the suspension of dextran and charcoal. The final incubation dilution of the antiserum was $1: 30,000$. The incubation time for the hormoneantibody reaction was $2 \mathrm{hr}$. Dextran-charcoal suspension $(1 \mathrm{ml})$ was added to each tube to separate free from antibody-bound hormone.

In our laboratory, this assay gave the following reliability data: $200 \mu \mathrm{l}$ plasma from an ovariectomized cow gave a mean concentration of $25 \cdot 5 \pm$ S.E. $4.9 \mathrm{pg}(n=13)$; the same plasma fortified with 20,100 and $300 \mathrm{pg}$ and run in duplicate gave corrected concentrations of 16 and 18, 110 and 135, and 280 and $310 \mathrm{pg}$, respectively; $200 \mu \mathrm{l}$ distilled water gave a concentration which never exceeded $12 \mathrm{pg}$ which is equivalent to $0.06 \mathrm{ng} / \mathrm{ml}$; samples from a pool of plasma obtained from a cow on Day 11 of an oestrous cycle were included in every assay, and these gave a mean concentration of $7 \cdot 8 \pm$ S.E. $0 \cdot 3 \mathrm{ng} / \mathrm{ml}$ $(n=22)$ and an interassay coefficient of variation of $15.3 \%$; the mean difference between concentrations from duplicates of random samples placed in each assay was $0.25 \pm$ S.E. $0.03 \mathrm{ng} / \mathrm{ml}(n=24)$.

\section{RESULTS}

Ovarian morphology and fertilization data are presented in Table 1. Both mean and variance of ovulation rate increased with dose of PMSG. In Group 2, there was a close relation between the number of fertile ova and ovulation rate $(r=0.96, P<0.01, n=8)$, but not in Group 3. It was observed that most ovulations occurred in cows with the longest interval between PMSG injection and oestrus in Group $2(r=0.90, P<0.01, n=8)$, but not in Group 3. One heifer in Group 2 and five in Group 3 had many follicles greater than $10 \mathrm{~mm}$ 
in diameter at slaughter. The large numbers of cystic-appearing follicles were the primary cause of the high ovarian weights in Group 3.

Mean plasma progesterone concentrations before and during oestrus are shown in Text-fig. 1. These graphs are based on a normalization of the data using the time of initial detection of oestrus $(0 \mathrm{hr})$ as the reference point. The mean concentration began to decrease significantly about $60 \mathrm{hr}$ before oestrus in Groups 1 and 2 and about $36 \mathrm{hr}$ before oestrus in Group 3. The level was below $1 \mathrm{ng} / \mathrm{ml}$ plasma (progesterone trough) for $24 \mathrm{hr}$ before oestrus in Group 1, $12 \mathrm{hr}$ before oestrus in Group 2 and $6 \mathrm{hr}$ before oestrus in Group 3. The mean rates of regression of CL (from peak levels to the trough) for the three groups were compared, and the rate for Group 3 was significantly steeper than that for Groups 1 and $2(P<0.01)$. Thus, the concentration remained high for a longer period in Group 3 after PMSG administration, and then fell at a greater rate $(\mathrm{ng} / \mathrm{ml} / \mathrm{hr})$ once the level began to decrease.

Table 1. The effect of PMSG on ovarian morphology and fertilization rate in heifers

\begin{tabular}{|c|c|c|c|}
\hline & \multicolumn{3}{|c|}{ Treatment } \\
\hline & Control & $\begin{array}{c}1600 \text { i.u. } P M S G \text { on } \\
\text { Day } 16 \text { of cycle }\end{array}$ & $\begin{array}{c}3200 \text { i.u. PMSG on } \\
\text { Day } 16 \text { of cycle }\end{array}$ \\
\hline $\begin{array}{l}\text { Interval from Day } 16 \text { until oestrus } \\
\text { No. of ovulations } \\
\text { No. of fertile ova } \\
\text { No. of non-fertile ova } \\
\text { No. of ova not received } \\
\text { No. of follicles }>10 \mathrm{~mm} \text { diameter } \\
\text { Total ovarian wt }(\mathrm{g})\end{array}$ & $\begin{array}{l}4 \cdot 9 \pm 1 \cdot 4 * \\
1 \cdot 0 \pm 0 \cdot 0 \\
1 \cdot 0 \pm 0 \cdot 0 \\
0 \cdot 0 \\
0 \cdot 0 \\
0.5 \pm 0.5 \\
10 \cdot 1 \pm 2 \cdot 8\end{array}$ & $\begin{array}{r}4 \cdot 0 \pm 1 \cdot 3 \\
6 \cdot 4 \pm 5 \cdot 0 \\
4 \cdot 4 \pm 4 \cdot 6 \\
0 \cdot 0 \pm \\
2 \cdot 0 \pm 0 \cdot 5 \\
6 \cdot 4 \pm 11 \cdot 0 \\
29 \cdot 3 \pm 12 \cdot 7\end{array}$ & $\begin{array}{r}4 \cdot 0 \pm 1 \cdot 6 \\
12 \cdot 6 \pm 4 \cdot 7 \\
4 \cdot 8 \pm 5 \cdot 7 \\
3 \cdot 0 \pm 2 \cdot 1 \\
4 \cdot 7 \pm 2 \cdot 9 \\
22 \cdot 0 \pm 13 \cdot 0 \\
103 \cdot 0 \pm 53 \cdot 5\end{array}$ \\
\hline
\end{tabular}

* Mean \pm S.E.

The effect of PMSG treatment on mean plasma oestrogen concentrations is shown for the three groups of cows in Text-fig. 1. The mean rates of increase in oestrogen concentration were $0.08,1.0$ and $1.2 \mathrm{pg} / \mathrm{ml} / \mathrm{hr}$ for Groups 1,2 and 3 , respectively, measured over the 4-day period before oestrus. The rates were significantly different from one another $(P<0 \cdot 05)$. For Group 2 , the maximum concentration of plasma oestrogen was related to the interval from PMSG injection to oestrus $(r=0.82, P<0.013, n=8)$. Plasma oestrogen was not correlated with follicle number at slaughter or the maximum plasma $\mathrm{LH}$ concentrations at oestrus. For Group 3, the maximum oestrogen concentration was not correlated with any of these parameters.

The assumed quantity of oestrogen secreted during the period of increasing blood levels (based on the area under the individual curves) was related to the number of ovulations (Text-fig. 2). Ovulation rate generally was related to the total amount of oestrogen but the slope of the regression line was steepest in the group that received the highest dose of PMSG.

It should be noted that, in the untreated cows (Group 1), the progesterone concentration had fallen to less than $1 \mathrm{ng} / \mathrm{ml}$ at about the same time that the oestrogen concentration exceeded $10 \mathrm{pg} / \mathrm{ml}$. In the animals treated with PMSG, oestrogen levels began to increase before progesterone levels reached 

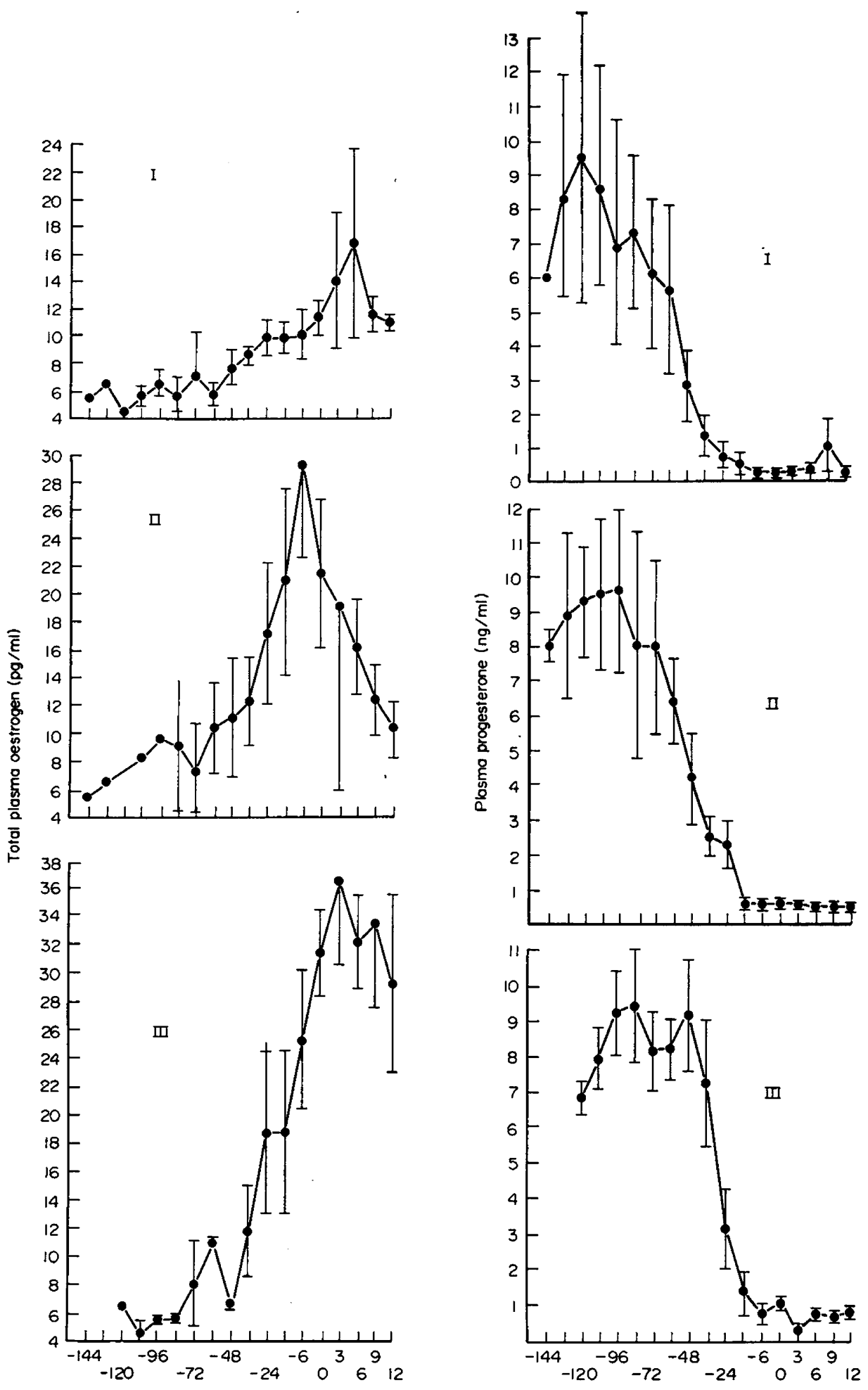

TEXT-FIG. 1. Plasma oestrogen concentrations and plasma progesterone concentrations before and during oestrus in beef heifers receiving 0 i.u. (I), 1600 i.u. (II) and 3200 i.u. (III) of PMSG. 
the trough. The area which is common to both the progesterone and oestrogen curves was measured and related to ovulation rate in Text-fig. 2. There was a good fit to the regression lines within each group of cows, and the difference between groups is obvious.

During the first $12 \mathrm{hr}$ of oestrus, oestrogen levels in Group 2 fell rapidly to a concentration of $10 \mathrm{pg} / \mathrm{ml}$, which is similar to that found in Group 1. In Group 3 , however, the level fell only slightly from a peak level of $36.3 \mathrm{pg} / \mathrm{ml}$ to 28.9 $\mathrm{pg} / \mathrm{ml}$.

The effect of PMSG treatment on plasma LH concentrations during the period before and after oestrus is shown in Text-fig. 3. During the period after injection of PMSG until about $6 \mathrm{hr}$ before oestrus, there were no significant differences between groups in the plasma $\mathrm{LH}$ concentrations $(P>0.05)$. In

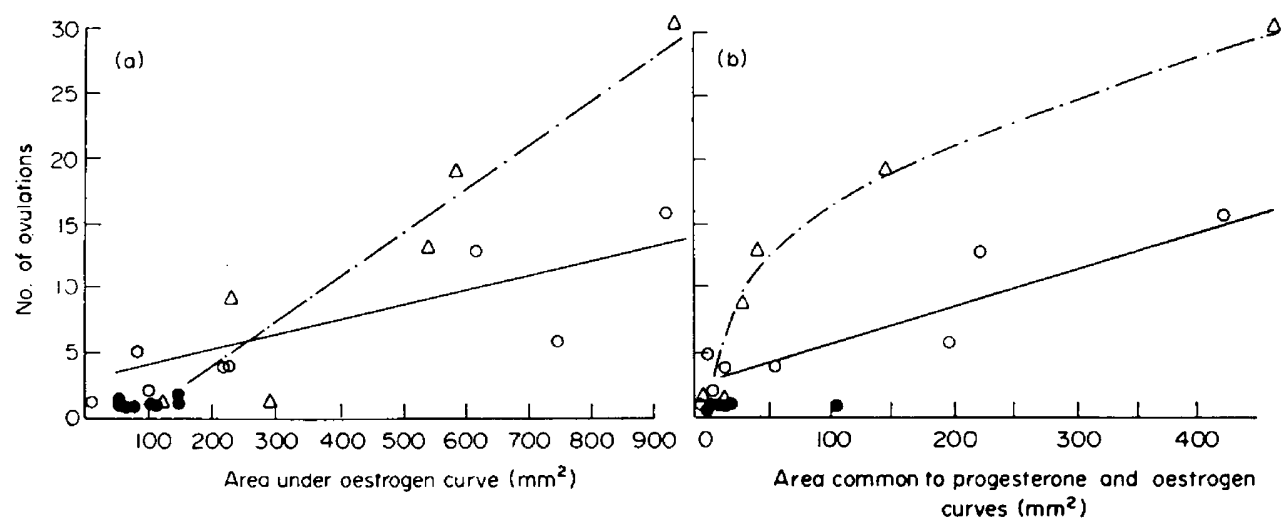

Text-Fig. 2. (a) A comparison of ovulation rate with the area under the oestrogen curve for each cow. 0 i.u.; $O, 1600$ i.u.; $\triangle, 3200$ i.u. (b) A comparison of ovulation rate versus the area under the curve common to both progesterone and oestrogen in each cow. 0 i.u.; O, 1600 i.u.; $\triangle, 3200$ i.u.

Groups 2 and 3, the mean LH levels began to increase about $6 \mathrm{hr}$ before oestrus, reaching peak levels at the time oestrus was detected. In Group 1, mean LH concentrations did not begin to rise until after oestrus was detected, the peak levels being observed $6 \mathrm{hr}$ later. Six of the eight cows in each of the treated groups compared with two cows in the untreated group had exhibited maximum levels of LH within $3 \mathrm{hr}$ after the onset of oestrus. There was no correlation between number of ovulations and the maximum level of $\mathrm{LH}$ during oestrus in either Group $2(r=0 \cdot 19, P>0 \cdot 05, n=8)$ or Group $3(r=0.01$, $P>0.05, n=8)$.

\section{DISCUSSION}

The doses of PMSG administered to heifers in this experiment had marked effects on ovarian morphology in terms of ovulation and follicle numbers. In addition, there was a substantial effect on endocrine status in terms of plasma oestrogen, progesterone and LH concentrations.

The lower dose of PMSG induced the ovulation of as many fertile ova per 

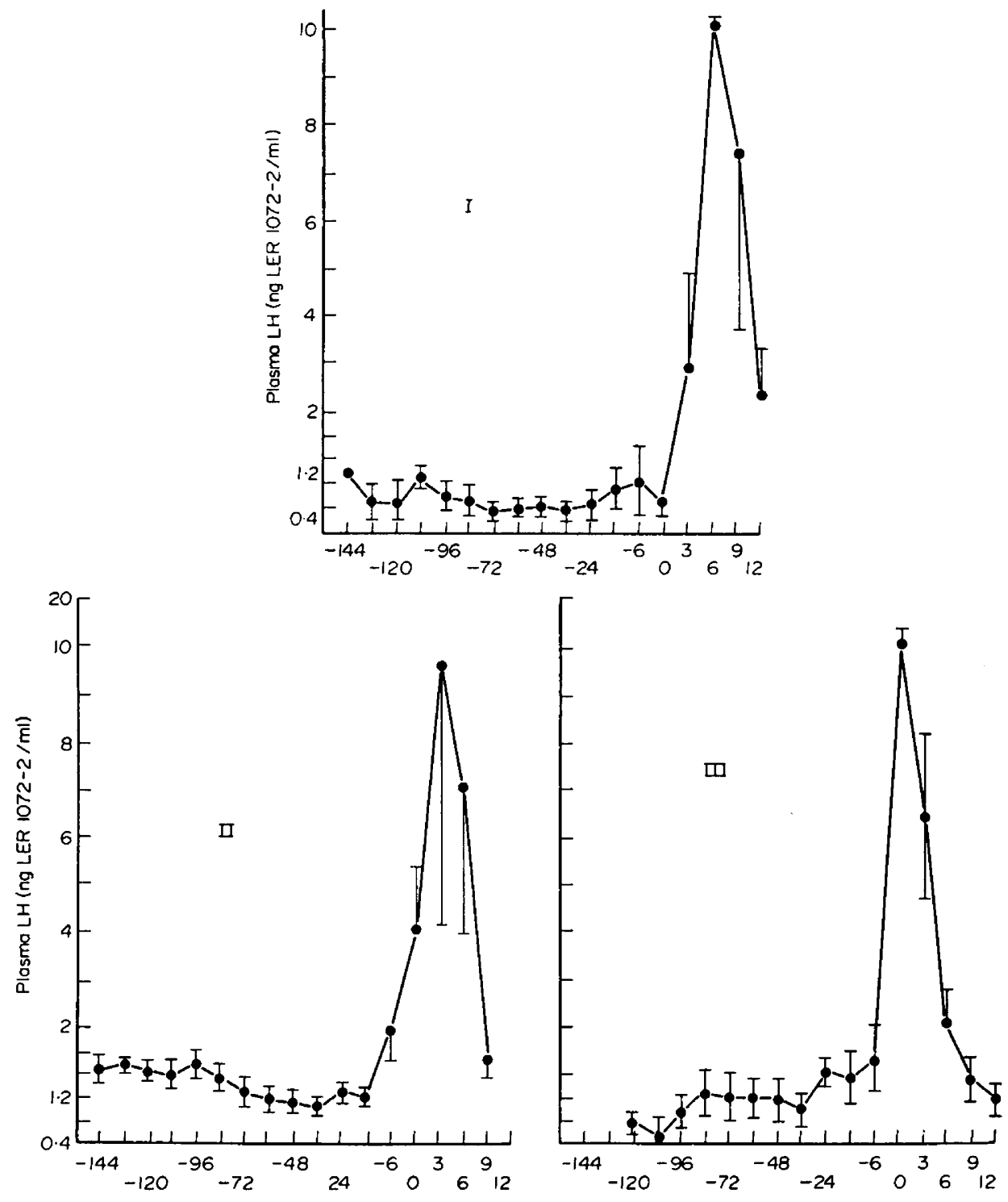

Hours before or after oestrus

TExT-FIG. 3. Concentrations of LH in plasma before and during oestrus in beef heifers receiving 0 i.u. (I), 1600 i.u. (II) and 3200 i.u. (III) of PMSG.

heifer as the higher dose while causing a lesser disturbance of the endocrine status. At both doses of PMSG, heifers having the longest intervals before oestrus ( 5 and 6 days) produced the most ovulations. In a report by $\mathrm{Hafez}$, Jainudeen \& Lindsay (1965), more ovulations were produced after a 4-day interval than after 2, 3 and 5 days.

Evidently, PMSG stimulated luteal function since there was a dose-response relationship between PMSG and the length of time that plasma progesterone 
remained at high levels after Day 16. Pregnant mares' serum gonadotrophin has both LH and FSH properties (Lamond, 1960); thus, the exogenous hormone probably exerted a luteotrophic effect on the CL. Once the CL began to regress, this process occurred more rapidly in the PMSG-treated animals than in the untreated animals. Since the interval from Day 16 of the oestrous cycle until the time at which mean plasma progesterone declined was less in the untreated group than in the treated groups, it might have been expected that the interval from Day 16 until oestrus would have been less in the untreated group. This did not occur. The interval was less in the treated groups. Oestrus in the treated groups may have been hastened in the face of higher plasma progesterone levels by the greatly increased plasma oestrogen levels.

The progesterone trough was shortest in Group 3. This was also the group with highest incidence of excessive numbers of unovulated follicles. It can be seen from Text-fig. 2 that the majority of follicles ovulated only when oestrogen levels began to rise before progesterone declined (i.e. the large area common to both progesterone and oestrogen curves). It can be inferred that the ovulation rate was poorest when the rapidly growing follicles failed to produce quantities of oestrogen while progesterone was still being secreted. Since ovulation rate and total oestrogen production are related, the critical variable controlling ovulation rate seems to be the numbers of follicles induced to grow and secrete oestrogen before the CL begins to regress.

An important influence on the ova and genital tract would be expected to be the two- to threefold greater oestrogen concentrations just before oestrus and during the early phase of oestrus in the PMSG-treated animals. Excessive oestrogen appeared to be a serious drawback, however, only in Group 3 in which the level $12 \mathrm{hr}$ after onset of oestrus was approximately three times greater than the level in the other two groups. It would seem that the factor that would be detrimental to ovarian and uterine function during ovulation, fertilization and implantation would be the prolongation of high concentrations and not a higher concentration per se.

It is generally believed that an increase in oestrogen level is involved in the 'LH surge' at oestrus (Sawyer, 1964; Scaramuzzi, Tillson, Thorneycroft \& Caldwell, 1971). There was a relation between the total amount of oestrogen produced and the time of the 'LH surge' among the treatments-the greater the oestrogen production, the earlier the surge. There was no consistent relation, however, between the beginning of the oestrogen rise (or the occurrence of the oestrogen peak) and the LH surge. Clearly, the controlling mechanisms have to take into account an interaction between progesterone and oestrogen, as well as the rate of growth of follicles. The low correlation between the LH output during oestrus and ovulation rate indicates that secretion of $\mathrm{LH}$ or its utilization is not a strict function of the number of large follicles which are induced to grow.

\section{ACKNOWLEDGMENTS}

We wish to thank Dr Walter Johnston, Mrs Sarah Bierley, Mrs Tina Lake and $\mathrm{Mr}$ Bob Rauton for the technical assistance needed to complete this experiment. 
The antiserum used in the assay of total plasma oestrogen was supplied by Dr B. V. Caldwell, Yale University, New Haven, Conn. The antiserum against bovine LH (B-225) was supplied by Dr G. D. Niswender, Colorado State University, Ft Collins, Colo. Bovine LH (LER-1072-2) was supplied by Dr L. E. Reichert, Jr, Emory University, Atlanta, Ga. The antiserum (IHT-R111516-1) used in the assay of plasma progesterone was supplied by Dr I. H. Thorneycroft, University of California, Los Angeles.

\section{REFERENCES}

Bellows, R. A. \& SHort, R. E. (1972) Superovulation and multiple births in beef cattle. F. Anim. Sci. 34, Suppl. 1, 66.

Dziuk, P. J., Donker, J. A., Nichols, J. R. \& Petrersen, W. E. (1958) Problems associated with the transfer of ova between cattle. Tech. Bull. Minn. agric. Exp. Stn, 222.

Gordon, I., Williams, G. \& Edwards, J. (1962) The use of serum gonadotrophin (PMS) in induction of twin pregnancy in the cow. 7. agric. Sci., Camb. 59, 143.

Hafez, E. S. E., Jainudeen, M. R. \& Lindsay, D. R. (1965) Gonadotrophin-induced twinning and related phenomena in beef cattle. Acta endocr., Copenh. Suppl. 102.

Hammond, J., JR (1949) Induced twin ovulations and multiple pregnancy in cattle. J. agric. Sci., Camb. $39,22$.

Henricks, D. M., Dickey, J. F. \& HiLL, J. R. (1971) Plasma estrogen and progesterone levels in cows prior to and during estrus. Endocrinology, 89, 1350.

Henricks, D. M. \& Lamond, D. R. (1972) Hormonal interrelations in beef cows with induced multiple ovulations. Nature, Lond. 235, 222.

LAMOND, D. R. (1960) Induction of ovulation in mice with placental gonadotrophins. F. Endocr. 20, 277.

LAMOND, D. R. (1970) The effects of pregnant mare serum gonadotropin (PMSG) on ovarian function of beef heifers, as influenced by progestins, plane of nutrition and fasting. Aust. F. agric. Res. 21, 153.

Lamond, D. R. (1972) Hormonal induction of multiple ovulation in the bovine. F. Anim. Sci. 34, 901 (Abstr.).

Niswender, G. D., Reichert, L. E., Midgley, A. R. \& Nalbandov, A. V. (1969) Radioimmunoassay for bovine and ovine luteinizing hormone. Endocrinology, 84, 1166.

SAWYer, C. H. (1964) Control of secretion of gonadotropins. In: Gonadotropins. Their Chemical and Biological Properties and Secretory Gontrol, p. 113. Ed. H. H. Cole. Freeman, San Francisco.

Scaramuzzi, R. J., Tillson, S. A., Thorneycroft, I. H. \& Galdwell, B. V. (1971) Action of exogenous progesterone and estrogen on behavioral estrus and luteinizing hormone levels in the ovariectomized ewe. Endocrinology, 88, 1189.

Thorneycroft, I. H. \& Stone, S. G. (1972) Radioimmunoassay of serum progesterone in women receiving oral contraceptive steroids. Contraception, 5, 129. 